\title{
Validation of Stratification-Driven Phytoplankton Biomass and Nutrient Concentrations in the Northeast Atlantic Ocean as Simulated by EC-Earth
}

\author{
Nomikos Skyllas ${ }^{1}\left(\mathbb{D}\right.$, Richard Bintanja ${ }^{2,3}$, Anita G. J. Buma ${ }^{3}$, Corina P. D. Brussaard ${ }^{1}{ }^{(}$, \\ Matthias Gröger ${ }^{4,+}{ }^{+}$, Jenny Hieronymus ${ }^{4}$ and Willem H. van de Poll ${ }^{3, *}$ \\ 1 Department of Marine Microbiology and Biogeochemistry, NIOZ Royal Netherlands Institute for Sea \\ Research, and Utrecht University, 1790 AB Den Burg, The Netherlands; nomikos.skyllas@nioz.nl (N.S.); \\ corina.brussaard@nioz.nl (C.P.D.B.) \\ 2 Royal Netherlands Meteorological Institute (KNMI), 3731 GA De Bilt, The Netherlands; bintanja@gmail.com \\ 3 Department of Ocean Ecosystems, Energy and Sustainability Research Institute Groningen, University of \\ Groningen, 9747 AG Groningen, The Netherlands; a.g.j.buma@rug.nl \\ 4 Swedish Meteorological and Hydrological Institute, SMHI SE-601 76 Norrköping, Sweden; \\ matthias.groger@smhi.se (M.G.); jenny.hieronymus@smhi.se (J.H.) \\ * Correspondence: w.h.van.de.poll@rug.nl \\ + Current address: Department of Physical Oceanography and Instrumentation, Leibniz Institute for Baltic Sea \\ Research Warnemünde, 18119 Rostock, Germany.
}

Received: 26 September 2019; Accepted: 17 October 2019; Published: 21 October 2019

\begin{abstract}
We validated simulations of the Earth system model (ESM) EC-Earth-NEMO of present-day temperature, salinity, nutrient, and chlorophyll a profiles with in situ observations in the Northeast Atlantic Ocean $\left(29-63^{\circ} \mathrm{N}\right)$. Simulations with standard parametrization (run 1) and improved parametrization of vertical mixing (run 2) were compared. Run 1 showed shallower mixed layer depths (MLDs) in spring as compared to observations owing to lower salinities in the upper $200 \mathrm{~m}$ of the subpolar North Atlantic $\left(>55^{\circ} \mathrm{N}\right)$. This coincided with a mismatch with observed timing and magnitude of the phytoplankton spring bloom. In contrast, the model performed well south of $55^{\circ} \mathrm{N}$. Run 2 showed improved springtime MLD, phytoplankton dynamics, and nutrient distributions in the subpolar North Atlantic. Our study underlines the sensitivity of subpolar North Atlantic phytoplankton blooms to surface freshening, suggesting that future fresh-water inflow from Arctic and Greenland Ice sheet melting could significantly affect phytoplankton productivity. These findings contribute to the generic validation of the EC-Earth ESM and underline the need for rigorous validation of physics-biology links, in particular the sub polar North Atlantic where complex seasonal stratification/vertical mixing processes govern upper ocean phytoplankton productivity.
\end{abstract}

Keywords: North Atlantic; Earth system models; EC-Earth; NEMO; PISCES; carbon cycle; phytoplankton; Stratiphyt; model validation; stratification; nutrients; chlorophyll a; mixed layer depth

\section{Introduction}

The oceans play a critical role in the global carbon cycle since they harbor enormous pools of inorganic as well as organic carbon [1]. Phytoplankton are responsible for almost $50 \%$ of global photosynthesis and store carbon in the deep ocean for long periods of time (the biological pump), thereby influencing long-term climate trends [2]. Yet, phytoplankton biomass, expressed as chlorophyll-a concentrations, also varies strongly on interannual and decadal timescales $[3,4]$. This variability correlates with climatic variations that regulate the availability of irradiance, nutrients, viral lysis, grazers, and the sinking speed of the cells [5-8]. Since phytoplankton growth and species 
composition influence marine productivity up to the highest trophic levels, including harvestable stocks, studying the climate processes and interactions that control phytoplankton dynamics is of vital importance in predicting the future of marine ecosystems under a changing climate.

Vertical mixing and stratification are important mechanisms controlling phytoplankton growth, since these determine to a large extent the availability of light and nutrients [6,9]. In many temperate to polar seas and oceans, phytoplankton growth exhibits a pronounced seasonal pattern: In winter, convection expands the mixed layer, causing a nutrient-rich water column, and reduced irradiance exposure, resulting in low phytoplankton growth $[5,6,9,10]$. In spring, the shoaling of the mixed layer (ML), owing to salinity or temperature stratification, confines phytoplankton close to the surface where it is exposed to increased irradiance and nutrients. Therefore, the upper chlorophyll maximum (UCM) is the most productive state. The termination of the winter convection and the onset of the spring stratification are crucial processes regulating seasonal phytoplankton dynamics [9-12]. The onset of stratification reduces exchange with deeper nutrient rich water. Therefore, the spring bloom depletes surface nutrients and growth becomes nutrient limited $[9,13]$. This results in a regenerative system with smaller sized algae, the formation of a deep chlorophyll maximum (DCM) and reduced primary production by the surface ocean phytoplankton. This state dominates year-round in the permanently stratified oligotrophic regions (e.g., subtropical North Atlantic), and also occurs seasonally at higher latitude [6,14].

Earth system models (ESMs) are valuable tools to study the ocean's productivity and its sensitivity to climate. ESMs operate beyond the 'traditional' coupled atmosphere-ocean general circulation models (AOGCMs) by elucidating interactions between the global climate's subsystems. These include ocean biogeochemistry, dynamic vegetation, atmospheric chemistry, dynamic ice sheets, and carbon cycle components. ESMs are more comprehensive compared to the traditional coupled ocean atmosphere models as they involve more climate compartments and thus, allow for the most realistic simulation of feedback loops across different part of the climate system. Recently, the European Centre for Medium-range Weather Forecast (ECMWF) member states developed an ESM (EC-Earth) with the ECMWF weather prediction model as a starting point. While the current version of EC-Earth is essentially a state-of-the-art AOGCM [15], a number of additional climate components such as ocean biogeochemistry and carbon cycle modules are being integrated into the EC-Earth model for use in the Coupled Model Intercomparison Project (CMIP) phase 6 [16]. EC-Earth uses the community ocean model Nucleus for European Modelling of the Ocean (NEMO) coupled to Pelagic Interactions Scheme for Carbon and Ecosystem Studies (PISCES). PISCES' development started in 1997 and complexity of the model increased over time, yet its coupling to ESMs is new and thus requires validation of e.g., marine carbon cycle components. Traditionally global biogeochemistry and carbon cycle models are validated primarily against climatological mean atlases such as the WOA [17-19]. By contrast, comparison with real time in situ data is rare but highly required because only this data allows robust comparison on the process level. Therefore, the aim of the present study was to compare NEMO-PISCES with detailed field observations of water column characteristics (temperature, salinity, density, mixed layer depth, stratification), phytoplankton biomass (chlorophyll a), and nutrient (nitrate) concentrations obtained during two cruises in the North East Atlantic Ocean.

We used output from two simulations of NEMO-PISCES-v2 standalone for the current climate, of which the years 2009 (run 1 and 2) and 2011 (run 1) were compared with matching observational data from two cruises (Stratiphyt 1: Summer 2009, and 2: Spring 2011). These cruises with observations from 29 to $63^{\circ} \mathrm{N}$ in the North Atlantic Ocean were selected because of the key role of the North Atlantic in global climate (change) and ocean circulation. For example, North Atlantic deep-water formation accounts for $20 \%$ of the net ocean uptake of $\mathrm{CO}_{2}$, which may change under a warming climate and weakened Atlantic overturning circulation $[1,20,21]$. Furthermore, this transect covered a strong meridional gradient in stratification processes with permanent stratification in the subtropics and seasonal stratification in the temperate zones. This gradient allowed us to assess the model performance in various water column characteristics as well as their interaction with phytoplankton dynamics 
(phenology, DCM, UCM, and deep mixing states). In addition, we used chlorophyll a remote sensing data (ESA-MERIS) for more detailed spatial validation of the model. This validation effort aimed to identify possible model biases to direct future improvements of the ocean biogeochemistry and carbon cycle modules of EC-Earth. Our focus was on spatial (along transect), interannual, and seasonal variability with respect to chlorophyll a concentration, nutrients (nitrate) and water column characteristics (temperature, salinity, density, and vertical mixing).

\section{Methodology}

\subsection{Stratiphyt Cruises}

Stratiphyt I (July 15-August 11, 2009) and II (April 6-May 3, 2011) cruises covered a transect from the Canary Islands $\left(29^{\circ} \mathrm{N}\right)$ to Iceland $\left(63^{\circ} \mathrm{N}\right)$ (Figure 1). During each cruise, 32 stations were sampled in the upper $250-550 \mathrm{~m}$ by the RV Pelagia $[5,22]$. Chlorophyll a (Chl a) of discrete samples was determined by HPLC as explained by van de Poll et al. (2013) [5]. Surface $(10 \mathrm{~m})$ nitrate $\left(\mathrm{NO}_{3}\right)$ concentrations were obtained from discrete samples as described by Mojica et al. (2015) and van de Poll et al. (2013) [5,22]. Mixed layer depth (MLD) was derived from the conductivity-temperature-depth (CTD, binned to $1 \mathrm{~m}$ ) profiles using a difference of $0.01 \mathrm{~kg} \mathrm{~m}^{-3}$ in potential density $(\sigma \theta)$ from the reference depth of $10 \mathrm{~m}$ $\left(\Delta \sigma \theta=0.01 \mathrm{~kg} / \mathrm{m}^{3}\right)$. This criterion was used because it defined MLD in the model.

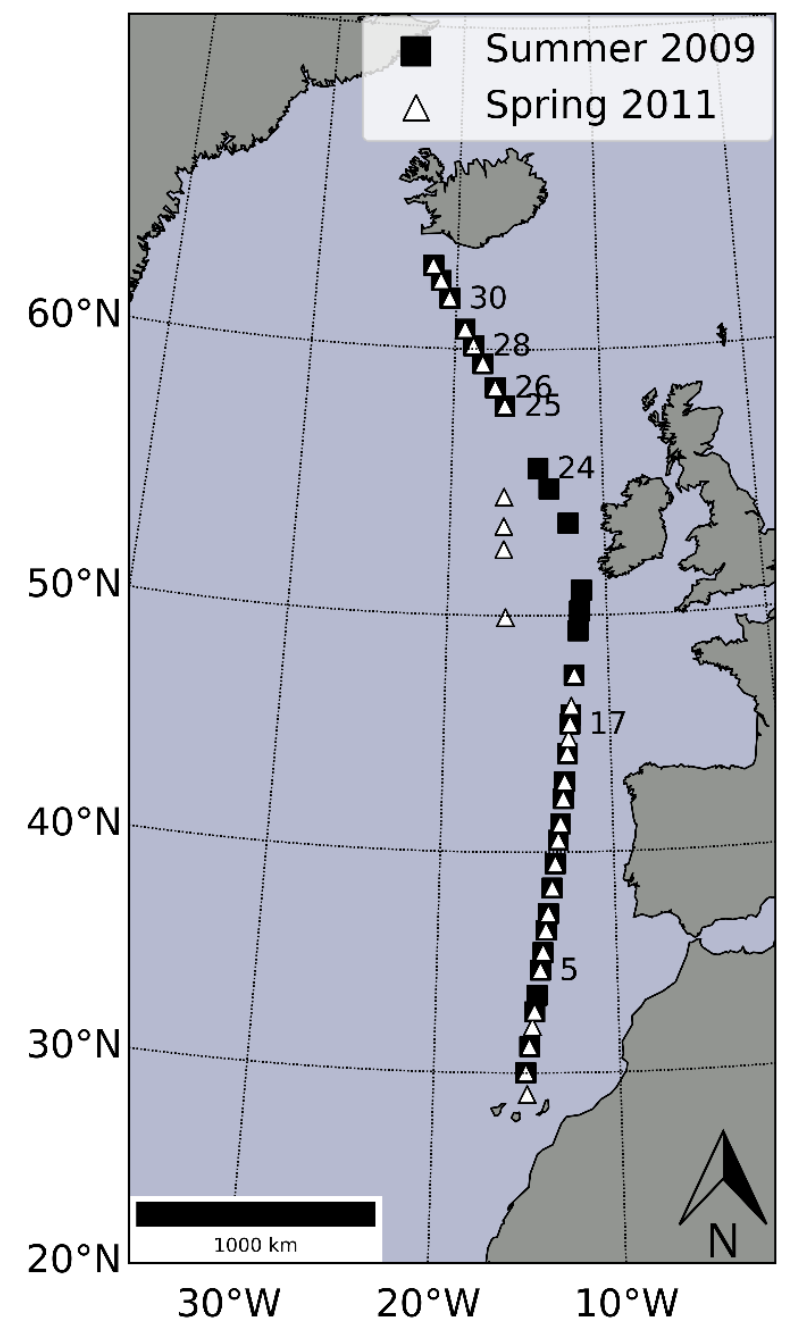

Figure 1. Northeast Atlantic Ocean with stations of the spring (April-May 2011, white triangles) and summer (July-August 2009, black squares) Stratiphyt cruises. 


\subsection{The NEMO-PISCES Model}

NEMO (Nucleus for European Modelling of the Ocean) is a state-of-the-art 3D physical ocean model that can be coupled with other models to study the interactions between the climate subsystems [23]. We used NEMO v3.6 at a horizontal resolution of one degree and a vertical resolution of 75 levels (layer thickness ranges from $0.5 \mathrm{~m}$ at the surface to $610 \mathrm{~m}$ at the bottom). NEMO uses a tri-polar grid with poles over northern North America, Siberia, and Antarctica. The horizontal discretization is done on a curvilinear C-grid. NEMO is a primitive equation model with a free surface. It uses a turbulent kinetic energy (TKE) scheme for vertical mixing, a partial step implementation for the z-coordinate, a bottom boundary scheme to mix dense water and total variance dissipation for horizontal advection. Horizontal tracer diffusion follows Gent-Mc-Williams parameterization of eddy-induced turbulence.

PISCES (pelagic interactions scheme for carbon and ecosystem studies) [19] simulates marine biological productivity and describes the biogeochemical cycles of the main nutrients $(\mathrm{P}, \mathrm{N}, \mathrm{Si}, \mathrm{Fe})$ and of carbon. PISCES-v2 consists of 24 compartments in total. It includes five modeled limiting nutrients: $\mathrm{NO}_{3}$ and $\mathrm{NH}_{4}, \mathrm{PO}_{4}$, silicate (Si), and iron (Fe), with $\mathrm{NO}_{3}, \mathrm{NH}_{4}$, and $\mathrm{PO}_{4}$ following a constant Redfield ratio in every organic compartment. Nitrogen $(\mathrm{N})$ undergoes fixation and denitrification in the open ocean and the upper sediments. The external sources of nutrients, meaning river run-off and dust, are independent from the Redfield ratio. Four living compartments are modeled, consisting of two phytoplankton (nanophytoplankton and diatoms) and two zooplankton size classes (micro and mesozooplankton). For phytoplankton, the $\mathrm{Fe} / \mathrm{C}, \mathrm{Chl} \mathrm{a} / \mathrm{C}$, and $\mathrm{Si} / \mathrm{C}$ (only for diatoms) ratios are prognostically predicted by the model. Regarding zooplankton, only its total biomass is modeled. The $\mathrm{C} / \mathrm{N} / \mathrm{P} / \mathrm{O}_{2}$ ratios are assumed constant and do not vary across species. The Redfield ratio used here is $122 / 16 / 1(\mathrm{C} / \mathrm{N} / \mathrm{P})$ and the $\mathrm{O} / \mathrm{C}$ ratio is 1.34 . Bacteria are not modeled but are parameterized during the remineralization of dead organic material.

Two stand-alone (i.e., no interactive atmosphere) simulations of NEMO/PISCES-v2 were performed for the period 1958 to 2016 (run 1) and for the period 1948 to 2009 (run 2), with spin-up runs of 358 and 310 years, respectively. Run 1 was forced at the surface using DFS (Drakkar Forcing Set) 5.2 fields developed by the DRAKKAR Group (2007). This uses the ERA-interim (ERAi) reanalysis boundary conditions, which consist of precipitation, downward short-and long-wave radiation, $10 \mathrm{~m}$ winds, and $2 \mathrm{~m}$ air humidity and temperature from 1958 to 2016. These were combined with ERA40 reanalysis for the $10 \mathrm{~m}$ wind and $2 \mathrm{~m}$ air humidity and temperature from 1958 to 1978. ERA40 reanalysis records are interpolated to those of ERAi: 3-h and 0.7.

A second simulation (run 2) was performed using adjustments recommended by the EC-Earth development group to NEMO (physical) parameters with the goal to improve upper ocean vertical mixing and stratification in subpolar North Atlantic. Changes consist of: a) ocean turbulent kinetic energy penetration depth from 1 (run 1 ) to $0, b$ ) ocean Langmuir waves cell size from 0.15 (run 1 ) to 0.2 and c) snow thermal conductivity from 0.30 (run 1 ) to $0.40 \mathrm{~W} \mathrm{~K}^{-1} \mathrm{~m}^{-1}$. The first two parameters affect ocean vertical mixing, whereas snow thermal conductivity has an effect on sea ice extent. Run 2 was forced at the surface using the protocol of the Coordinated Ocean-ice Reference Experiments (CORE-II) [24,25]. This forcing data set covers the years 1948 to 2009, for which the interannually varying atmospheric state from Large and Yeager (2009) [24] was used in combination with river runoff data from Dai and Trenberth (2002) and Dai et al. (2009) [26,27].

For the analyses in this study we use the NEMO/PISCES model output from the years 2009 and 2011 (run 1) and 2009 (run 2) of model fields regridded onto a regular $1 \times 1$ degree grid. Monthly averages (the smallest temporal resolution) of surface salinity, temperature, potential density, $\mathrm{Chl}$ a, and nitrate concentrations of NEMO/PISCES v2 were evaluated for the model grid points that contain the exact coordinates of each of the 32 Stratiphyt stations (Figure 1). Furthermore, representative stations along the cruise transect were selected to evaluate depth profiles of salinity, temperature, potential density, $\mathrm{Chl}$ a, and nitrate concentrations (stations 5, 17, 23, 30, 32). In addition, $\mathrm{Chl}$ a remote sensing data were used to expand the comparison of the phytoplankton seasonal dynamics north of $55^{\circ} \mathrm{N}$ for 2009 (stations 24, 26, 28, 30). The remote sensing data were obtained from the European Space Agency 
(ESA) website (Medium Resolution Imaging Spectrometer (MERIS), https://earth.esa.int/web/guest/ missions/esa-operational-eo-missions/envisat/instruments/meris). In summary, we compare Stratiphyt observations taken on specific days with monthly model data (maximum temporal model resolution is one month), and monthly satellite data, for the locations where the observations were taken.

\section{Results}

\subsection{Temperature, Salinity, Mixed Layer Depth}

In spring, sea surface temperature (SST) ranged from $18-20^{\circ} \mathrm{C}$ at the southern stations to $8.5^{\circ} \mathrm{C}$ at $63^{\circ} \mathrm{N}$, whereas summer SST ranged from $23^{\circ} \mathrm{C}$ at $29^{\circ} \mathrm{N}$ to $12.4^{\circ} \mathrm{C}$ at the northernmost station (Figure 2a). Modelled SSTs were slightly underestimated in most stations during summer (average SST observed: $17.4 \pm 3.4^{\circ} \mathrm{C}$; model run 1: $17.0 \pm 3.6^{\circ} \mathrm{C}$ ). Vertical profiles of measured and modelled temperature showed similar patterns, with almost homogeneous temperatures in the upper $200 \mathrm{~m}$ during spring and warming of the mixed layer during summer (Figure 3a). Sea surface salinity (SSS) ranged from 36.8 PSU in the south to $35.5 \mathrm{PSU}$ in the north $\left(63^{\circ} \mathrm{N}\right)$ during spring and summer observations (Figure 2b). Modelled SSSs south of $52^{\circ} \mathrm{N}$ were on average $0.5 \pm 0.2$ PSU lower than observations of 2009 and 2011. Modelled SSS between $52-63^{\circ} \mathrm{N}$ were on average $0.7 \pm 0.2$ (summer) and $0.5 \pm 0.2$ PSU (spring) lower than observed. The model spring and summer salinity deviations were observed in the upper 200-300 m, whereas salinity at greater depth was close to observations (Figure $3 b$ ). Accordingly, modelled potential density was lower than observations in the upper 200-300 m (Figure 3c). South of $52^{\circ} \mathrm{N}$, observed and modelled spring mixed layer depth (MLD) was on average $24 \pm 15$ and $25 \pm 7 \mathrm{~m}$, whereas this was $22 \pm 9$ and $15 \pm 3 \mathrm{~m}$ during summer (Figure 2c). Between $52-63^{\circ} \mathrm{N}$, NEMO-PISCES run 1 underestimated spring-time MLDs (Figure 2c) (observed: $129 \pm 58 \mathrm{~m}$; run 1: $99 \pm 32 \mathrm{~m}$ ), whereas summer MLDs showed better agreement (observed $19 \pm 5 \mathrm{~m}$, run 1: $17 \pm 2 \mathrm{~m}$ ). 

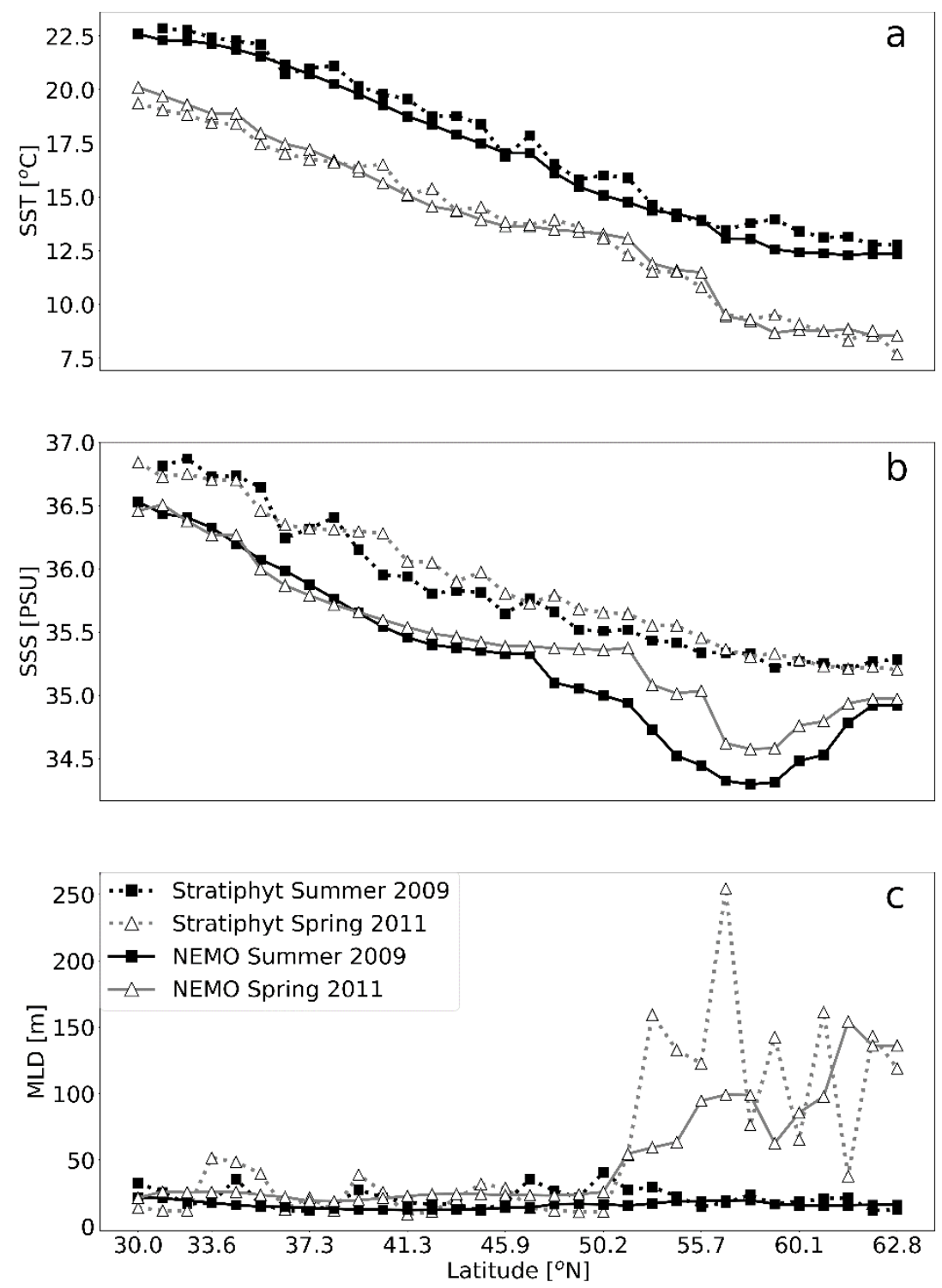

Figure 2. Sea surface temperature (SST) (a), sea surface salinity (SSS) (b), and mixed layer depth (MLD) (c), of Stratiphyt and NEMO (nucleus for European modelling of the ocean) run 1. Model results are April-May (2011) and July-August (2009) averages of stations shown in Figure 1. 

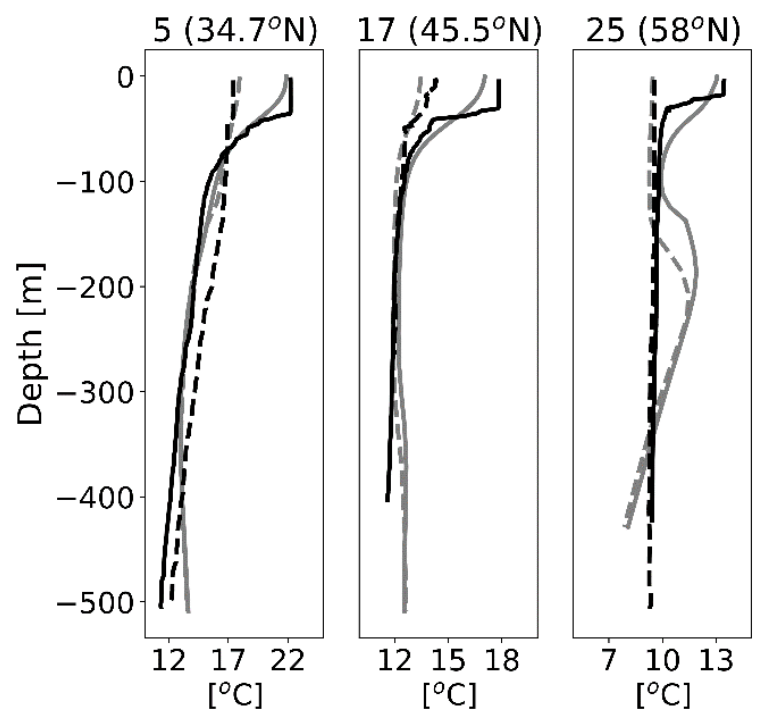

$30\left(61.7^{\circ} \mathrm{N}\right)$
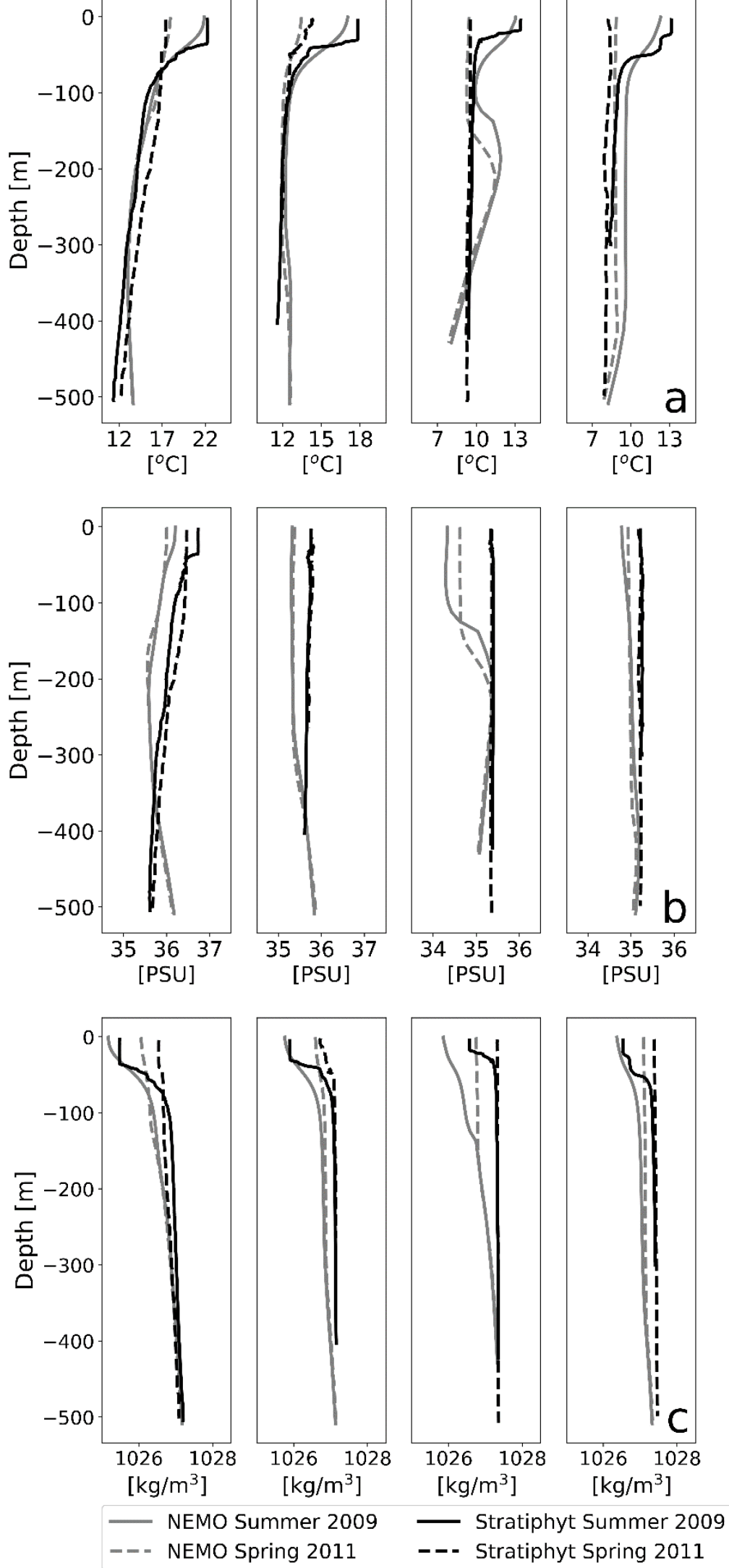

Figure 3. Temperature (a), salinity (b), and potential density (c) in the upper $500 \mathrm{~m}$ of Stratiphyt and NEMO (nucleus for European modelling of the ocean) run 1 at stations 5, 17, 25, and 30. Model results are April-May (2011) and June-August (2009) averages. 
Spring-time SSTs of run 2 (2009) showed a higher residual mean square error (RMSE) than that of run 1 when compared to observed SSTs during spring 2011 (Table 1A, Figure 4a). In contrast, summer SST showed lower RMSE during run 2 as compared to run 1 . The second model run improved salinity and potential density in the upper 200-300 $\mathrm{m}$ along the transect in spring and summer, as compared with observations, resulting in lower RMSE (Table 1B, Figure $4 \mathrm{~b}, \mathrm{c}$ ). South of $52^{\circ} \mathrm{N}$ salinity increased by $0.3 \pm 0.03 \mathrm{PSU}$, whereas this was $0.44 \pm 0.2 \mathrm{PSU}$ between $52-63^{\circ} \mathrm{N}$ (summer and spring average). North of $52^{\circ} \mathrm{N}$ modelled MLDs of the spring of 2009 increased on average from $70 \pm 19$ (run 1) to $90 \pm$ $38 \mathrm{~m}$ (run 2) (Figure 4c). Nevertheless, run 2 RMSE increased when comparing MLDs of run 1 and 2 with spring 2011 observations (Table 1C). Spring MLDs south of $52^{\circ} \mathrm{N}$ decreased (run 1: $37 \pm 6$; run 2: $32 \pm 6 \mathrm{~m}$ ), whereas summer MLDs increased (run 1: $16 \pm 3$; run 2: $19 \pm 3 \mathrm{~m}$ ). Compared to run 1 the winter-early spring MLDs (monthly resolution) north of $52^{\circ} \mathrm{N}$ (up to March 2009) increased from 134-257 to 192-353 $\mathrm{m}$ in run 2 (Figure 5). The shallowest MLDs were established in June during run 1 and 2 (Figure 5). The summer and autumn MLDs were less affected by changed parametrization of run 2, in contrast to the convection dominated winter-early spring mixing depths (Figure 5).
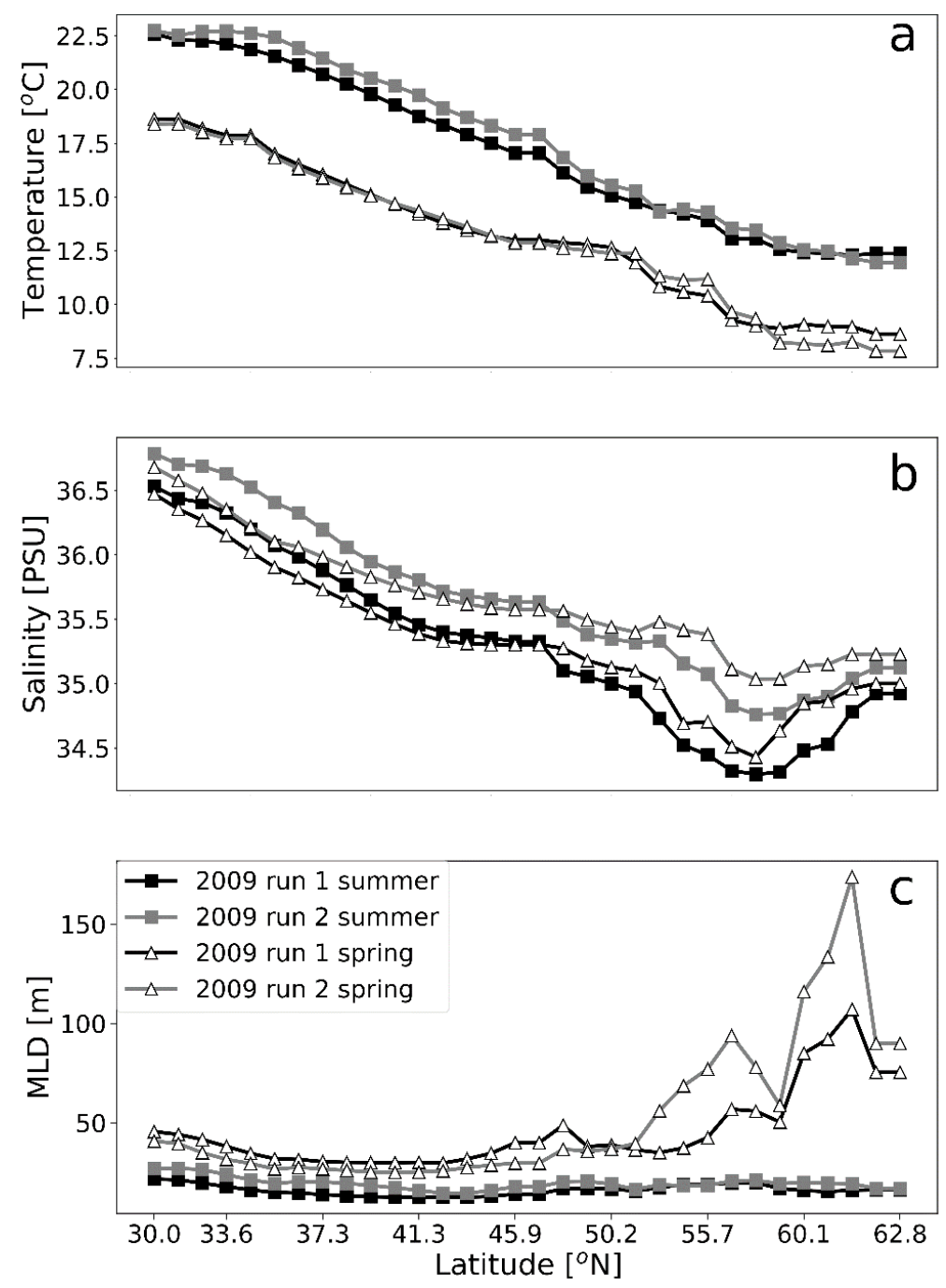

Figure 4. Sea surface temperature (SST) (a), sea surface salinity (SSS) (b), and mixed layer depth (MLD) (c) of NEMO run 1 and run 2. Model results are for spring 2009 (April-May averages) and summer 2009 (July-August averages). 
Table 1. Root mean square error (RMSE) of Stratiphyt observations and NEMO-PISCES (nucleus for European modelling of the ocean - pelagic interactions scheme for carbon and ecosystem studies) run 1 and 2 for stations $<52^{\circ} \mathrm{N}(\mathrm{n}=21)$ and $>52^{\circ} \mathrm{N}(\mathrm{n}=11)$ for a: Sea surface temperature; b: Sea surface salinity; and c: Mixed layer depth. Spring observations of Stratiphyt (2011) were compared with NEMO -PISCES of spring 2009 run 1 and 2. Summer observations of Stratiphyt (2009) were compared with NEMO-PISCES summer 2009 run 1 and 2.

\begin{tabular}{ccccccc}
\hline \multicolumn{7}{c}{ A: Sea Surface Temperature } \\
\hline Latitude & Spring & run 1 & run 2 & Summer & run 1 & run 2 \\
\hline$<52^{\circ} \mathrm{N}$ & 0.49 & 1.00 & 0.63 & 0.47 \\
$>52^{\circ} \mathrm{N}$ & 0.48 & 0.62 & 0.70 & 0.69 \\
\hline \multicolumn{7}{c}{ B: Sea Surface Salinity } \\
\hline Latitude & Spring & run 1 & run 2 & Summer & run 1 & run 2 \\
\hline$<52^{\circ} \mathrm{N}$ & & 0.54 & 0.27 & 0.47 & 0.16 \\
$>52^{\circ} \mathrm{N}$ & 0.77 & 0.30 & 0.77 & 0.34 \\
\hline \multicolumn{7}{c}{ C: Mixed Layer Depth } \\
\hline Latitude & Spring & run 1 & run 2 & Summer & run 1 & run 2 \\
\hline$<52^{\circ} \mathrm{N}$ & 12.9 & 16.7 & 10.4 & 8.8 \\
$>52^{\circ} \mathrm{N}$ & 76.9 & 85.8 & 5.3 & 4.5 \\
\hline
\end{tabular}
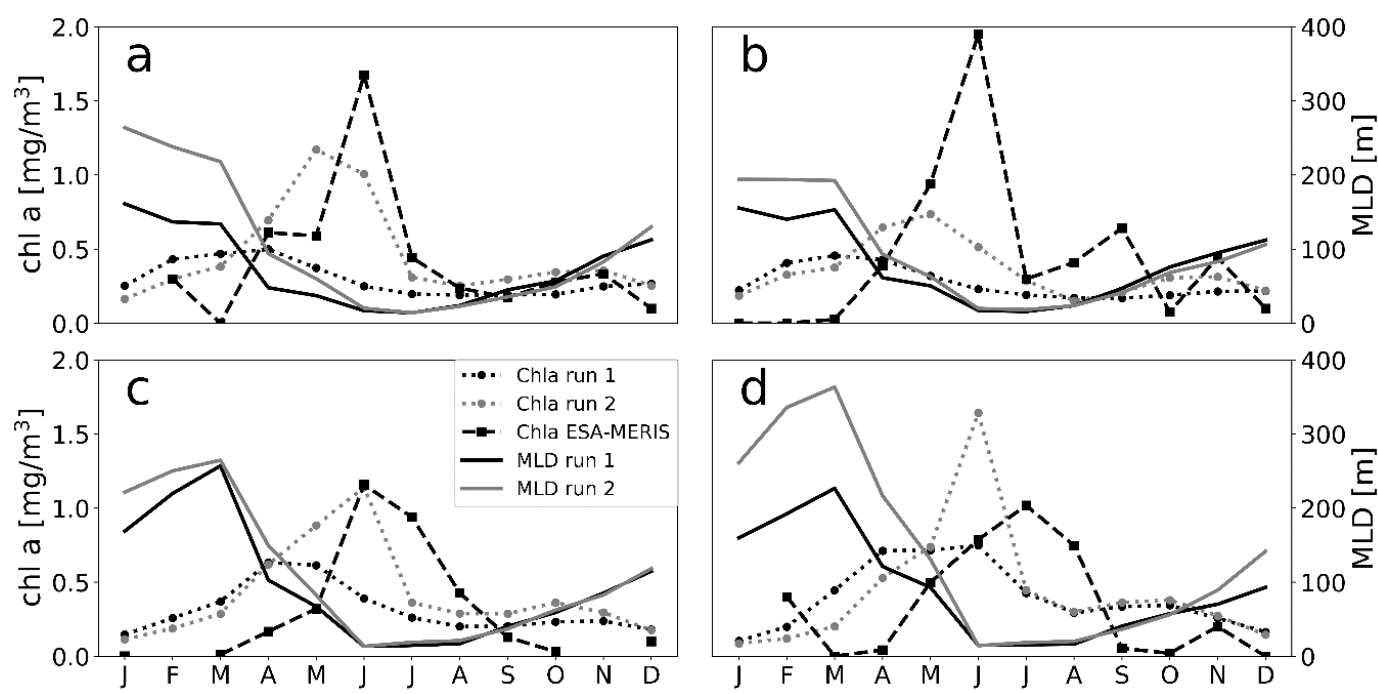

Figure 5. Monthly averages of surface chlorophyll a (Chl a, top $10 \mathrm{~m}$ ) and mixed layer depth (MLD) of NEMO-PISCES (nucleus for European modelling of the ocean - pelagic interactions scheme for carbon and ecosystem studies) run 1 and 2, combined with monthly averaged remote sensing Chl a (Meris) for stations at $55.7^{\circ} \mathrm{N}(\mathbf{a}), 58.7^{\circ} \mathrm{N}(\mathbf{b}), 60.1^{\circ} \mathrm{N}(\mathbf{c})$, and $62.8^{\circ} \mathrm{N}(\mathbf{d})$ during 2009.

\subsection{Surface Nitrate Concentrations}

Summer and spring surface nitrate of Stratiphyt and NEMO-PISCES run 1 was depleted to on average $0.06 \pm 0.10 \mathrm{mmol} \mathrm{m}^{-3}$ south of $43^{\circ} \mathrm{N}$ (Figure $6 \mathrm{a}$ ). North of $43^{\circ} \mathrm{N}$, observed surface nitrate concentrations increased to a maximum of $13 \mathrm{mmol} \mathrm{m}^{-3}$ in spring. Modelled (run 1) surface nitrate followed the same pattern, but with two-fold lower maximum concentrations (Figure 6b). Measured and modelled nitrate concentrations below $400 \mathrm{~m}$ were similar (not shown). Model run 1 and observed surface nitrate concentrations north of $45^{\circ} \mathrm{N}$ were in better agreement during summer, increasing to a maximum of $2 \mathrm{mmol} \mathrm{m}^{-3}$. During summer, a difference between observations and model outcomes was observed between $50-55^{\circ} \mathrm{N}$, where sampling stations were located on the continental shelf and close to the coast of Ireland (Figure 6). 


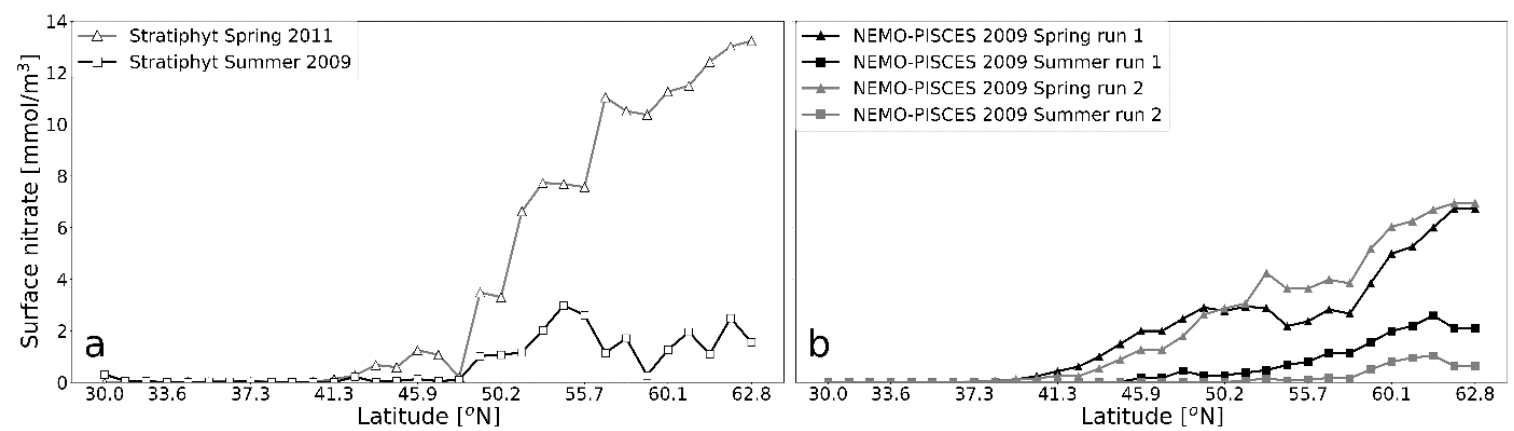

Figure 6. Surface nitrate concentrations (upper $15 \mathrm{~m}$ ) of Stratiphyt (a) and NEMO-PISCES (nucleus for European modelling of the ocean - pelagic interactions scheme for carbon and ecosystem studies) run 1 and 2 (b) during spring and summer. Model results are April-May (2011) and July-August (2009) averages.

Run 2 resulted in higher maximal spring time surface nitrate concentrations north of $55^{\circ} \mathrm{N}$ (run 1: $4.6 \pm 1.6$; run 2: $5.5 \pm 1.3 \mathrm{mmol} \mathrm{m}^{-3}$ ) and lower concentrations between $40-55^{\circ} \mathrm{N}$ (run 1: $1.8 \pm 0.9$; run 2: $1.7 \pm 1.3 \mathrm{mmol} \mathrm{m}^{-3}$ ) (Figure 6b). In summer, surface nitrate concentrations north of $45^{\circ} \mathrm{N}$ were lower than those predicted during run 1 (run 1: $1.1 \pm 0.8$; run 2: $0.3 \pm 0.4 \mathrm{mmol} \mathrm{m}^{-3}$ ).

\subsection{Chlorophyll a}

South of $40^{\circ} \mathrm{N}$ measured spring-time chlorophyll a ( $\mathrm{Chl}$ a) maxima were found at the deep chlorophyll maximum (DCM) (average $0.9 \pm 0.3 \mathrm{mg} \mathrm{m}^{-3}$ ), and between $40-48^{\circ} \mathrm{N}$ in the upper chlorophyll maximum (UCM) (average $1.4 \pm 0.3 \mathrm{mg} \mathrm{m}^{-3}$ ) (Figure 7a). North of $48^{\circ} \mathrm{N}$ spring-time $\mathrm{Chl}$ a was distributed over the deep mixed layer $\left(0.6 \pm 0.3 \mathrm{mg} \mathrm{m}^{-3}\right)$. In summer maximal Chl a was observed in DCMs (average $0.6 \pm 0.2 \mathrm{mg} \mathrm{m}^{-3}$ ) south of $47^{\circ} \mathrm{N}$, and in $\mathrm{UCMs}$ north of $55^{\circ} \mathrm{N}$ (average 1.1 $\pm 0.6 \mathrm{mg} \mathrm{m}^{-3}$ ) (Figure $7 \mathrm{~b}$ ). Model run 1 reproduced three predominant states in spring (Figure 7c): South of $40^{\circ} \mathrm{N}$, maximal Chl a was found in DCMs (average $0.30 \pm 0.04 \mathrm{mg} \mathrm{m}^{-3}$ ), and between $40-55^{\circ} \mathrm{N}$ maximal Chl a was found in UCMs (average $0.8 \pm 0.3 \mathrm{mg} \mathrm{m}^{-3}$ ). North of $55^{\circ} \mathrm{N}$ the model showed shallower UCMs in spring (average $107 \pm 28 \mathrm{~m}$ ), contrasting with the observations of a near-constant $\mathrm{Chl}$ a distributed over deep mixed layers (average $305 \pm 187 \mathrm{~m}$ ). The model calculated a maximum Chl a concentration of $0.8 \mathrm{mg} \mathrm{m}^{-3}$ in summer, which was two-fold lower than the measurements. In summer the model predicted DCMs south of $45^{\circ} \mathrm{N}$ in agreement with observations, but modelled DCMs extended further north, deviating from the UCMs as observed during the cruise (Figure 7d).

The maximum $\mathrm{Chl}$ a spring concentrations of run 2 increased by $38 \%$ compared to run 1 (run 1: 1.3; run 2: $\left.1.8 \mathrm{mg} \mathrm{m}^{-3}\right)$. Chl a of the DCM-dominated stations $\left(30-40^{\circ} \mathrm{N}\right)$ was similar between the two runs (Figure 7). The second run produced a more intense mid-latitude spring bloom $\left(1.8 \mathrm{mg} \mathrm{m}^{-3}\right)$, matching the observations (Figure 7a). North of $53^{\circ} \mathrm{N}$ spring-time $\mathrm{Chl}$ a also increased compared to run 1 . North of $55^{\circ} \mathrm{N}$, summertime Chl a of run 2 was in DCMs in contrast to observations that showed UCMs.

Surface Chl a of model run 1 and 2 (2009) were compared with remote sensing Chl a for four stations between 55 and $63^{\circ} \mathrm{N}$. Maximal surface $\mathrm{Chl}$ a of run 2 was higher compared to run 1 , which was in better agreement with remote sensing (Figure 5). Run 1 produced maximal surface $\mathrm{Chl}$ a in April, whereas this was in May and June during run 2. Remote sensing showed maximal surface Chl a in July (Figure 5). 


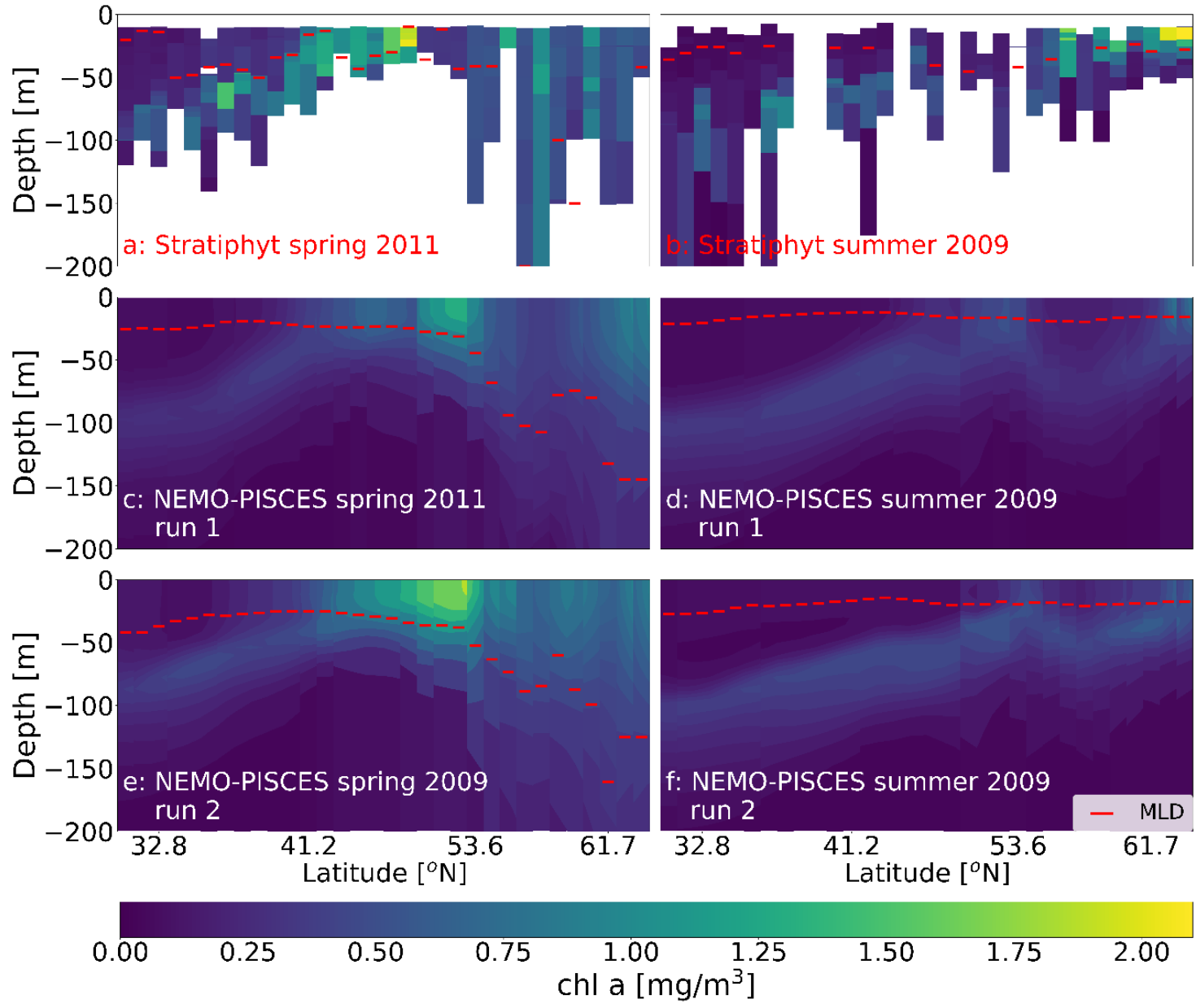

Figure 7. Chlorophyll a (Chl a) in the upper $200 \mathrm{~m}$ and mixed layer depth (MLD, red bars) of Stratiphyt $(\mathbf{a}, \mathbf{b})$, NEMO-PISCES (nucleus for European modelling of the ocean - pelagic interactions scheme for carbon and ecosystem studies) run $1(\mathbf{c}, \mathbf{d})$, and NEMO-PISCES run $2(\mathbf{e}, \mathbf{f})$ during spring $(\mathbf{a}, \mathbf{c}, \mathbf{e})$ and summer (b,d,f). Model Chl a and MLD are April-May (spring) and July-August (summer) averages.

\section{Discussion}

We used observations along a latitudinal transect to validate simulations of NEMO-PISCES, with a focus on stratification/vertical mixing and its effect on nutrient concentrations and phytoplankton $\mathrm{Chl}$ a. Model run 1 showed lower than observed salinity in the upper $200 \mathrm{~m}$, which was most pronounced in the subpolar North Atlantic $\left(55-62^{\circ} \mathrm{N}\right)$. Low surface salinity reduced mixed layer depth during winter and early spring, which lowered nutrient stocks available for phytoplankton blooms and caused earlier stratification in the sub polar north Atlantic. As a consequence, run 1 systematically underestimated springtime nitrate concentrations and caused earlier and weaker phytoplankton blooms in comparison to both cruises and remote sensing observations. Model run 1 salinity deviations were also observed during previous validation efforts of the EC-Earth model (https://dev.ec-earth.org) that used CORE forcing compared to DFS5.4 forcing that was used in our calculations, and in the interactively coupled ocean-atmosphere GCM from EC-Earth. These validation efforts also showed weak wintertime convection in the Labrador Sea and too shallow mixed layers over vast regions of the North Atlantic. This strongly implies that the salinity deviations of model run 1 were independent from atmospheric forcing. The run 1 salinity anomaly was most likely associated with an unrealistically strong fresh-water influx from the Arctic, as changes to thermal conductivity of snow (run 2) improved salinity in the North Atlantic. Although unrealistic for the compared years, this study underlined the potential importance of the Arctic Ocean fresh-water cycle and melting 
Greenland ice caps on the subpolar North Atlantic hydrographical conditions [28]. Climate change has pronounced effects on the fresh-water export to the North Atlantic, which is expected to increase in the coming decades. For example, enhanced melting of the Greenland Ice Sheet produces stronger inflow of fresh water. The declining and thinner Arctic sea ice can also be exported more easily into the subpolar North Atlantic [29,30]. Furthermore, an intensified hydrological cycle is expected to increase precipitation over the Arctic [28,31]. Moreover, these effects can be enhanced by the stronger thermal stratification that is predicted by most ESMs during previous phases of the Coupled Model Intercomparison Project (CMIP) [21,32]. Increased stratification by surface freshening and warming has pronounced effects on Arctic phytoplankton productivity [33] but also has the potential to influence the subpolar phytoplankton spring bloom magnitude by freshening the Arctic Ocean and North Atlantic, as indicated by our findings.

Run 2 with changed parametrization for vertical mixing and thermal conductivity of snow and with different forcing resulted in more realistic phytoplankton phenology and concentrations: Surface Chl a maxima (May, June) were closer to those of remote sensing (June, July). In contrast, the spring bloom of run 1 started in April due to earlier stratification, resulting in earlier depletion of surface nutrients and a subsequent transition to the DCM states during summer. Furthermore, NEMO-PISCES run 1 (Figure 5) predicted the onset of ML shoaling in March, two months earlier than observed during the 2011 Stratiphyt spring cruise, creating conditions for an earlier phytoplankton bloom [9]. Overall, the model adjustments of run 2 produced more realistic model outcomes, yet did not solve all deviations from observations. For example, run 2 spring-time surface nitrate concentrations were too low compared to observations of the sub polar North Atlantic. In contrast, NEMO-PISCES was more successful in predicting vertical ocean mixing, nutrient distribution, and phytoplankton dynamics in the subtropical North-Atlantic $\left(30-45^{\circ} \mathrm{N}\right)$. Furthermore, run 2 did not lead to major changes in the subtropical domain as compared to run 1.

PISCES validation by Aumont et al. (2015) concluded that the timing of phytoplankton blooms was driven by the timing of stratification [19]. In their validation efforts, the timing of the North Atlantic spring bloom was in accordance with observations. However, the study by Aumont et al. (2015) used PISCES coupled to the ORCA2-LIM v3.2 ocean general circulation model with 2-degree horizontal resolution, in contrast to the ocean model NEMO used here, which likely contributes to the differences [19].

Kone et al. (2009) [34] used PISCES coupled to a higher resolution version of NEMO (0.5 by 0.5 degree), and achieved $\mathrm{Chl}$ a concentrations and distribution in good agreement with observations. However, they still failed to reproduce bloom-dynamics in areas where mesoscale processes play a major role in phytoplankton dynamics such as the sub polar North Atlantic [34]. An increase in the NEMO-PISCES spatial resolution (as opposed to the $1 \times 1$ degree resolution used in this study) would enable a more detailed investigation of phytoplankton dynamics in the open ocean and coastal areas. In addition to increased model spatial resolution, inaccuracies regarding deep ocean ventilation potentially increased the uncertainty of the simulations, as this slow process can cause significant drifts in multiple ocean properties [17]. A few cycles of atmospheric forcing, as used in the two NEMO-PISCES v2 runs in this study, were likely not sufficient to reach equilibrium in the deep ocean.

Validation of model output with cruise data presents challenges due to differences in temporal and spatial resolution of the data. Stratiphyt sampling of less than one day per station provides a detailed snap shot, whereas models such as NEMO-PISCES (one month resolution) and remote sensing provide data on broader temporal and spatial scales. A temporal resolution of one month is insufficient to capture the dynamic changes in vertical water column structure of the high latitude winter-spring transition when vertical water column structure changes rapidly due to the cessation of convection and the establishment of stratification due to surface heating. Similarly, one day of sampling per station is clearly insufficient to draw robust conclusions regarding the timing of phytoplankton growth. Remote sensing products partly overcome this limitation, but they are restricted to surface Chl a and, especially at high latitudes, produce incomplete maps because of cloud cover [23]. More complete 
datasets that cover the entire year are needed in order to study the mechanisms governing the interactions between convective mixing, ML shoaling, and algal bloom onset. The aforementioned temporal and spatial issues could possibly be addressed by validating NEMO-PISCES with BGC-Argo float data in combination with remote sensing products and/or the use of datasets compiled by sampling at high latitudes. In order for NEMO-PISCES to be a reliable tool for studying the global carbon cycle, more validation studies (and consequent model adjustments) are required. These would need to focus on the complex, high-latitude regions of the ocean because the most prominent divergence between the model and observations were observed in the subpolar North Atlantic, and should ideally also include observations during winter-early spring.

This study underlines the great importance of stratification and mixing processes in determining phytoplankton bloom dynamics in the North Atlantic. These processes were found to be very sensitive to inputs of fresh water in the subpolar North Atlantic. This is of particular interest because this region experiences increased fresh-water inflow from the Arctic and from the melting of the Greenland Ice sheet $[29,30]$. Our study suggests that a continuation of this trend might influence phytoplankton bloom dynamics in this highly productive domain.

Author Contributions: N.S.: investigation, formal analysis, validation, visualization, writing, original draft preparation, review and editing; R.B.: methodology, conceptualization, software, resources, supervision, writing, review and editing; A.G.J.B.: conceptualization, supervision, writing, review and editing; C.P.D.B.: resources, review and editing; M.G.: methodology, software, resources, review and editing; J.H.: methodology, software, resources, review and editing; W.H.v.d.P.: conceptualization, resources, supervision, writing, original draft preparation, review and editing.

Funding: STRATIPHYT (ZKO-grant 839.08.420 for CPDB) was supported by the Earth and Life Sciences Foundation (ALW), which is subsidized by the Netherlands Organization for Scientific Research (NWO).

Acknowledgments: We thank captain and crew of RV Pelagia for their assistance during Stratiphyt. STRATIPHYT (ZKO-grant 839.08.420 for CPDB) was supported by the Earth and Life Sciences Foundation (ALW), which is subsidized by the Netherlands Organization for Scientific Research (NWO). Model simulations were supported through the EU H2020 project CRESCENDO (grant 641816). Model simulations were carried out on the facilities of national supercomputing Center Linköping, Sweden. We are grateful to the EC-Earth consortium for their contribution to the development of the Earth System Model EC-Earth.

Conflicts of Interest: The authors declare no conflict of interest.

\section{References}

1. Sabine, C.L.; Feely, R.A.; Gruber, N.; Key, R.M.; Lee, K.; Bullister, J.L.; Wanninkhof, R.; Wong, C.S.; Wallace, D.W.R.; Tilbrook, B.; et al. The Oceanic Sink for Anthropogenic CO2. Science 2004, 305, 367-371. [CrossRef] [PubMed]

2. Falkowski, P.G. The role of phytoplankton photosynthesis in global biogeochemical cycles. Photosynth. Res. 1994, 39, 235-258. [CrossRef] [PubMed]

3. Behrenfeld, M.J.; O'Malley, R.T.; Siegel, D.A.; McClain, C.R.; Sarmiento, J.L.; Feldman, G.C.; Milligan, A.J.; Falkowski, P.G.; Letelier, R.M.; Boss, E.S. Climate-driven trends in contemporary ocean productivity. Nature 2006, 444, 752-755. [CrossRef] [PubMed]

4. Osman, M.B.; Das, S.B.; Trusel, L.D.; Evans, M.J.; Fischer, H.; Grieman, M.M.; Kipfstuhl, S.; McConnell, J.R.; Saltzman, E.S. Industrial-era decline in subarctic Atlantic productivity. Nature 2019, 569, 551-555. [CrossRef] [PubMed]

5. Van De Poll, W.H.; Kulk, G.; Timmermans, K.R.; Brussaard, C.P.D.; Van Der Woerd, H.J.; Kehoe, M.J.; Mojica, K.D.A.; Visser, R.J.W.; Rozema, P.D.; Buma, A.G.J.; et al. Phytoplankton chlorophyll a biomass, composition, and productivity along a temperature and stratification gradient in the northeast Atlantic Ocean. Biogeosciences 2013, 10, 4227-4240. [CrossRef]

6. Hahn-Woernle, L.; Dijkstra, H.A.; Van Der Woerd, H.J. Sensitivity of phytoplankton distributions to vertical mixing along a North Atlantic transect. Ocean Sci. 2014, 10, 993-1011. [CrossRef]

7. Kristina, D.A.M.; Jef, H.; Steven, W.W.; Corina, P.D.B. Latitudinal variation in virus-induced mortality of phytoplankton across the North Atlantic Ocean. ISME J. 2016, 10, 500-513. [CrossRef] 
8. Behrenfeld, M.J.; Boss, E.S. Student's tutorial on bloom hypotheses in the context of phytoplankton annual cycles. Glob. Chang. Boil. 2017, 24, 55-77. [CrossRef]

9. Jurado, E.; Dijkstra, H.A.; Van Der Woerd, H.J. Microstructure observations during the spring 2011 STRATIPHYT-II cruise in the northeast Atlantic. Ocean Sci. 2012, 8, 945-957. [CrossRef]

10. Mignot, A.; Ferrari, R.; Claustre, H. Floats with bio-optical sensors reveal what processes trigger the North Atlantic bloom. Nat. Commun. 2018, 9, 190. [CrossRef]

11. Taylor, J.R.; Ferrari, R. Shutdown of turbulent convection as a new criterion for the onset of spring phytoplankton blooms. Limnol. Oceanogr. 2011, 56, 2293-2307. [CrossRef]

12. Behrenfeld, M.J. Abandoning Sverdrup's Critical Depth Hypothesis on phytoplankton blooms. F1000 Post-publication peer review of the biomedical literature 2010, 91, 977-989. [CrossRef] [PubMed]

13. Somavilla, R.; Rodriguez, C.; Lavín, A.; Viloria, A.; Marcos, E.; Cano, D. Atmospheric Control of Deep Chlorophyll Maximum Development. Geoscience 2019, 9, 178. [CrossRef]

14. Mignot, A.; Claustre, H.; Uitz, J.; Poteau, A.; D'Ortenzio, F.; Xing, X. Understanding the seasonal dynamics of phytoplankton biomass and the deep chlorophyll maximum in oligotrophic environments: A Bio-Argo float investigation. Glob. Biogeochem. Cycles 2014, 28, 856-876. [CrossRef]

15. Hazeleger, W.; Wang, X.; Severijns, C.; Ştefănescu, S.; Bintanja, R.; Sterl, A.; van der Wiel, K. EC-Earth V2.2: Description and validation of a new seamless earth system prediction model. Clim. Dyn. 2012, 39, 2611-2629. [CrossRef]

16. Griffies, S.M.; Danabasoglu, G.; Durack, P.J.; Adcroft, A.J.; Balaji, V.; Böning, C.W.; Chassignet, E.P.; Curchitser, E.; Deshayes, J.; Drange, H.; et al. OMIP contribution to CMIP6: experimental and diagnostic protocol for the physical component of the Ocean Model Intercomparison Project. Geosci. Model Dev. 2016, 9 , 3231-3296. [CrossRef]

17. Garcia, H.E.; Locarnini, R.A.; Boyer, T.P.; Antonov, J.I.; Baranova, O.K.; Zweng, M.M.; Johnson, D.R. World Ocean Atlas 2009, Volume 4: Nutrients (Phosphate, Nitrate, Silicate); US Government Printing Office: Washington, DC, USA, 2010; p. 398.

18. Ilyina, T.; Six, K.D.; Segschneider, J.; Maier, R.E.; Li, H.; Núñez, R.I. The global ocean biogeochemistry model HAMOCC: Model architecture and performance as component of the MPI-Earth System Model in different CMIP5 experimental realizations. J. Adv. Modeling Earth Syst. 2013, 5, 287-315. [CrossRef]

19. Aumont, O.; Ethe, C.; Tagliabue, A.; Bopp, L.; Gehlen, M. PISCES-v2: an ocean biogeochemical model for carbon and ecosystem studies. Geosci. Model Dev. 2015, 8, 2465-2513. [CrossRef]

20. Richard, H.; Stephanie, H.; Marja, K.; Christina, L.D.L.R.; Stuart, C.P.; Alex, J.P.; Jennifer, R.; Baris, S.; Andy, V.; Andrew, Y.; et al. The Biological Carbon Pump in the North Atlantic. Prog. Oceanogr. Part B 2014, 129, 200-218.

21. Fu, W.; Randerson, J.T.; Moore, J.K. Climate change impacts on net primary production (NPP) and export production $(\mathrm{EP})$ regulated by increasing stratification and phytoplankton community structure in the CMIP5 models. Biogeosciences 2016, 13, 5151-5170. [CrossRef]

22. Mojica, K.D.A.; Van De Poll, W.H.; Kehoe, M.; Huisman, J.; Timmermans, K.R.; Buma, A.G.J.; Van Der Woerd, H.J.; Hahn-Woernle, L.; Dijkstra, H.A.; Brussaard, C.P.D.; et al. Phytoplankton community structure in relation to vertical stratification along a north-south gradient in the Northeast Atlantic Ocean. Limnol. Oceanogr. 2015, 60, 1498-1521. [CrossRef]

23. NEMO Ocean Engine. Available online: https:/www.google.com.hk/url?sa=t\&rct=j\&q=\&esrc= s\&source=web\&cd=1\&ved=2ahUKEwilia_vuaPlAhUwyYsBHZlcCuAQFjAAegQIAxAC\&url= https $\% 3 \mathrm{~A} \% 2 \mathrm{~F} \% 2 \mathrm{Fwww}$. nemo-ocean.eu\%2Fwp-content $\% 2$ Fuploads\%2FNEMO_book.pdf\&usg= AOvVaw04Y9keaaF2GIljVijhCKfY (accessed on 21 October 2019).

24. Large, W.G.; Yeager, S.G. The global climatology of an interannually varying air-Sea flux data set. Clim. Dyn. 2009, 33, 341-364. [CrossRef]

25. Griffies, S.M.; Biastoch, A.; Böning, C.; Bryan, F.; Danabasoglu, G.; Chassignet, E.P.; England, M.H.; Gerdes, R.; Haak, H.; Hallberg, R.W.; et al. Coordinated Ocean-ice Reference Experiments (COREs). Ocean Model. 2009, 26, 1-46. [CrossRef]

26. Dai, A.; Trenberth, K.E. Estimates of Freshwater Discharge from Continents: Latitudinal and Seasonal Variations. J. Hydrometeorol. 2002, 3, 660-687. [CrossRef]

27. Dai, A.; Qian, T.; Trenberth, K.E.; Milliman, J.D. Changes in Continental Freshwater Discharge from 1948 to 2004. J. Clim. 2009, 22, 2773-2792. [CrossRef] 
28. Bintanja, R.; Selten, F.M. Future increases in Arctic precipitation linked to local evaporation and sea-ice retreat. Nature 2014, 509, 479-482. [CrossRef]

29. de Steur, L.; Peralta-Ferriz, C.; Pavlova, O. Freshwater Export in the East Greenland Current Freshens the North Atlantic. Geophysical Res. Let. 2018, 45, 13359-13366. [CrossRef]

30. Carmack, E.; Yamamoto-Kawai, M.; Haine, T.; Bacon, S.; Bluhm, B.; Lique, C.; Melling, H.; Polyakov, I.; Straneo, F.; Timmermans, M.-L.; et al. Freshwater and its role in the Arctic Marine System: Sources, disposition, storage, export, and physical and biogeochemical consequences in the Arctic and global oceans. J. Geophys. Res. Biogeosciences 2016, 121, 675-717. [CrossRef]

31. Bintanja, R.; Andry, O. Towards a rain-dominated Arctic. Nat. Clim. Chang. 2017, 7, 263-267. [CrossRef]

32. Steinacher, M.; Joos, F.; Frölicher, T.L.; Bopp, L.; Cadule, P.; Cocco, V.; Doney, S.C.; Gehlen, M.; Lindsay, K.; Moore, J.K.; et al. Projected 21st century decrease in marine productivity: a multi-model analysis. Biogeosciences 2010, 7, 979-1005. [CrossRef]

33. Coupel, P.; Ruiz-Pino, D.; Sicre, M.; Chen, J.; Lee, S.; Schiffrine, N.; Li, H.; Gascard, J. The impact of freshening on phytoplankton production in the Pacific Arctic Ocean. Prog. Oceanogr. 2015, 131, 113-125. [CrossRef]

34. Koné, V.; Aumont, O.; Lévy, M.; Resplandy, L.; Wiggert, J.D.; Hood, R.R.; Naqvi, S.W.A.; Brink, K.H.; Smith, S.L. Physical and biogeochemical controls of the phytoplankton seasonal cycle in the Indian Ocean: A modeling study. Extreme Events 2009, 185, 147-166. [CrossRef]

(C) 2019 by the authors. Licensee MDPI, Basel, Switzerland. This article is an open access article distributed under the terms and conditions of the Creative Commons Attribution (CC BY) license (http://creativecommons.org/licenses/by/4.0/). 